\title{
Effect of training on staff knowledge of screening and management of sepsis
}

\author{
Morten Lamberts", Dorthe Juul Rasmussen, Hanne Jørsboe \\ From Danish Society for Emergency Medicine: Research Symposium 2010 \\ Roskilde, Denmark. 20-21 May 2010
}

\section{Background}

At Nykøbing Falster Hospital, a mid-size community hospital, sepsis is among the most frequent causes of death. International studies have shown significant reduction in mortality, morbidity and healthcare resource consumption with early screening and treatment of sepsis. The Acute Division wanted to identify possible areas of interventions that could improve the treatment of sepsis by elucidating/clarifying clinical staff awareness of the criteria for sepsis screening and management.

\section{Methods}

An intervention study with measurement of the staff knowledge of the criteria for SIRS (severe inflammatory response syndrome), sepsis, severe sepsis and septic shock and how to manage sepsis. Target audience was care staff nurses working in the Acute Division.

Baseline and follow-up at 12 weeks were with a questionnaire survey. Responses could be made as correct, wrong and no answers. Interventions were teaching of clinical staff supplemented by knowledge-support tools such as pocket cards, posters and electronically accessible (regional) guideline. Effect of interventions was tested with non-parametric statistic.

\section{Results}

Baseline showed that only $18 \%$ knew the precise criteria for severe sepsis, $80 \%$ percent enrolled falsely blood pressure. At follow-up, 75\% knew criteria for severe sepsis. The following topics were improved to $100 \%$; how to culture the patient, intravenous saline treatment and when they have to call the anaesthesiologist, although only $50 \%$ knew the correct treatment with antibiotics.

\footnotetext{
* Correspondence: mortenlamberts@gmail.com Akutafdelingen, Nykøbing Falster Sygehus, Denmark
}

\section{Conclusion}

This study shows that training of the staff by teaching supported by pocket cards, posters and electronically accessible guideline improve staff knowledge of management of sepsis and especially screening of sepsis. It is a particular challenge in an acute division to provide the necessary training to staff working in different shifts. Although our study only focuses on staff knowledge a subsequent follow-up will show whether more patients are actually screened and correctly managed for sepsis.

Published: 17 September 2010

doi:10.1186/1757-7241-18-S1-P10

Cite this article as: Lamberts et al: Effect of training on staff knowledge of screening and management of sepsis. Scandinavian Journal of Trauma, Resuscitation and Emergency Medicine 2010 18(Suppl 1):P10.
Submit your next manuscript to BioMed Central and take full advantage of:

- Convenient online submission

- Thorough peer review

- No space constraints or color figure charges

- Immediate publication on acceptance

- Inclusion in PubMed, CAS, Scopus and Google Scholar

- Research which is freely available for redistribution

Submit your manuscript at www.biomedcentral.com/submit
C Biomed Central 